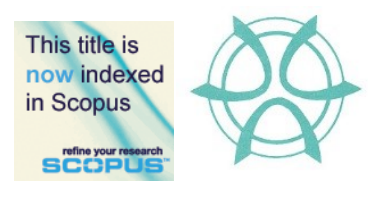

PLANNING MALAYSIA:

Journal of the Malaysian Institute of Planners

VOLUME 19 ISSUE 4 (2021), Page 1 - 11

\title{
DETERMINATION OF SPECIAL PERMIT RATE FOR LARGE- SCALE SOLAR DEVELOPMENT IN JOHOR BASED ON PLANNER PERSPECTIVE
}

\author{
Mohd Shahrizan Sahid ${ }^{1}$, Robiah Suratman ${ }^{2}$, Hishamuddin Mohd Ali ${ }^{3}$ \\ ${ }^{1,2,3}$ Faculty of Built Environment and Surveying \\ UNIVERSITI TEKNOLOGI MALAYSIA
}

\begin{abstract}
Over the past decade, the Malaysian government has put its effort into various programmes to promote solar energy in the country. As for now, Large Scale Solar (LSS) is the biggest programme conducted by Sustainable Energy Development Authority (SEDA) and permitted by Energy Commission (EC). As the large-scale solar does not have any proper guideline, especially in development approval consideration, Johor land administrators have put telecommunication tower development as a benchmark in approving large-scale solar developments that use the Special Permit method. However, the Special Permit fee appears unfitting for the development. Thus, this paper aims to determine the Special Permit rate for large-scale solar development which are profitable to the stakeholders. Its drawback is particularly related to solar radiance, which is the key criterion of site selection to develop the most profitable site. Selected respondents have been interviewed and the findings have led to a direction to standardise a legal framework for large-scale solar, especially in Johor.
\end{abstract}

Keywords: solar development, planning, profitable, large scale solar

\footnotetext{
${ }^{1} \mathrm{PhD}$ candidate at Universiti Teknologi Malaysia Email: shahrizan7@gmail.com
} 
Mohd Shahrizan Sahid, Robiah Suratman, Hishamuddin Mohd Ali

Determination Of Special Permit Rate for Large-Scale Solar Development in Johor Based on Planner Perspective

\section{INTRODUCTION}

The Malaysian government aspires to increase its contribution of 20 percent of renewable energy production by 2025, aligned with the Climate Change Convention and Paris Agreement agreed by the United Nations (UN) on the Sustainable Development Goals (SDGs) agenda. Thus, the government has endorsed a Renewable Energy Policy and a Renewable Energy Action Plan in April 2010 as a measure to strengthen the development of alternative energy, especially in the photovoltaic industry. Recognising the potential of solar energy generation in the country that can support the extinction of natural resources and profitable investment, the government has established Sustainable Energy Development Authority (SEDA) in 2010 with various program initiatives such as Feed in Tariff (FiT), Net Energy Metering (NEM), and Large Scale Solar (LSS).

The LSS program has been established in the $11^{\text {th }}$ Malaysia Plan (20162020) that aims to accelerate the increase of renewable energy production in the country. However, it has expanded to the next phase which involves new LSS capacity planned for 2020 to 2025 . This program started operations in 2017, and now has increased to 21 LSS in the country (Energy Commission, 2019). Moreover, the implementation of this program is subject to the bidding process through tenders conducted by the $\mathrm{EC}$ and there is no specific quota allocation by the state. So far, SEDA and EC has awarded around 1634.21 Megawatt of solar energy through the LSS program, their sprinkles are divided as shown in Figure 1.

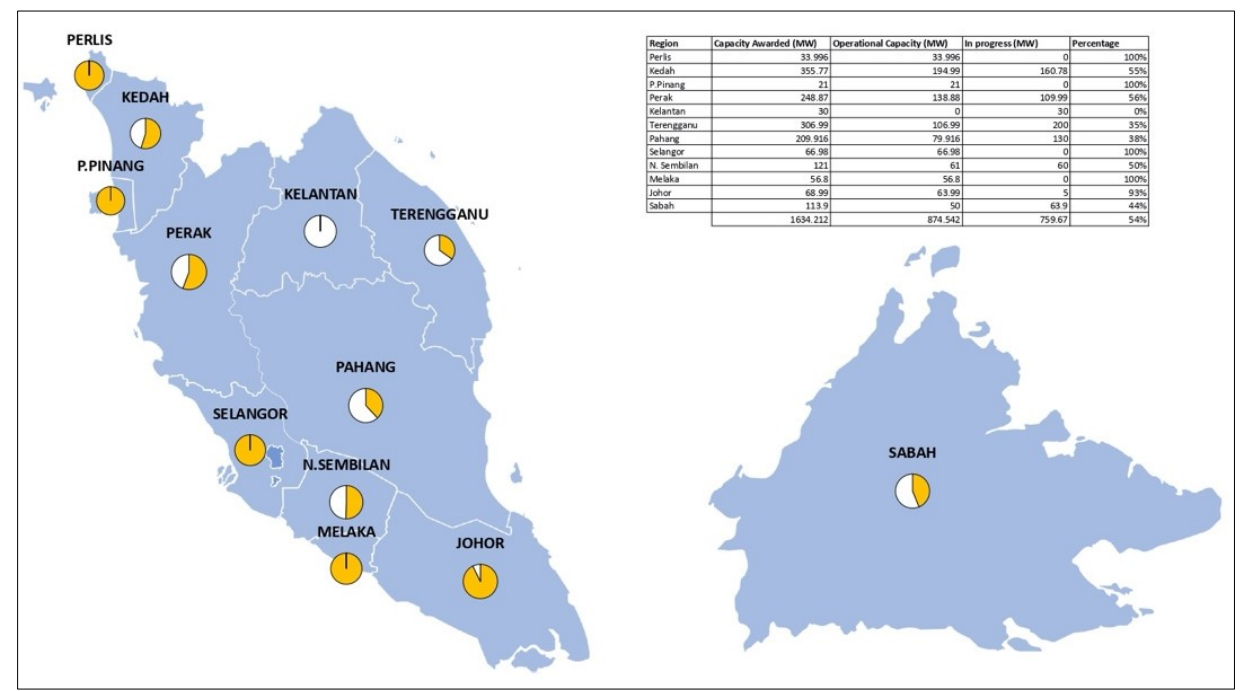

Figure 1: LSS Progress by Region Q1 2021

Sources: Energy Commission, 2021 
Taking into the current scenario of large-scale solar development in Johor, most of the developers that have been awarded with as much 68.99 Megawatt are not landowners. Typically, they will lease the potential farmland through an agreement with the landowner for a long time (Johor Land and Minerals Office, 2020). Besides that, some of the landowners and developers are partners through a cooperation agreement to use the land for large-scale solar development. In addition, the landowner can make additional profit by leasing their land to a developer (T. Grout and J. Ifft, 2018). A research in the United States found that landowners typically get around 250 to 2,000 per acre, per year for leasing their land for large-scale solar development (Solar Land Lease, 2020). In Johor, the implementation of a Special Permit to use agricultural land for non -agricultural purposes is stated in Rule 38D of the Johor Land Rules, read together with the circular of the Director of Lands and Minerals of Johor No 1/2006. This circular describes the application method, jurisdiction to approve Special Permits as well as the application fee and permit approval fee. However, the circular only details the implementation of Special Permits for the purpose of construction of telecommunication towers and the fee seems unsuitable for large-scale solar development. This is because large-scale solar needs larger land acres, needing approximately 2.5 acres per Megawatt (MW) energy produced, compared to a telecommunication tower that only uses a 20 -metre square of land for each development (PLANMalaysia, 2019; Solarvest, 2018). This leads to land administrators to revise and set up a new Special Permit fee especially for largescale solar development. Thus, N.A. Naamandadin et al. (2018) addressed the relationship between solar radiance and the power generated, and it would be the most important variable or criterion to set the new Special Permit fee especially for large-scale solar development.

\section{RESEARCH BACKGROUND: SITE SELECTION CRITERIA FOR LARGE-SCALE SOLAR DEVELOPMENT}

Recently, interest in sustainable energy supply has increased exponentially as there will be an increase in world energy in the next few decades (Edenhofer et al., 2014). Furthermore, energy is a key element of sustainable development, economic growth, and well-being. Recognising the global energy resource crisis, solar energy is one of the cleanest energy alternatives, providing minimal environmental impact with cheaper costs and unlimited supply (Urmee et al., 2009). According to the great potential of this energy, it would be a good motivation to developers to invest in large-scale solar development and the most profitable site would be selected.

Issues arise as large-scale development is still new in the country and land administrators do not have any proper guidance in approving the application. Based on current practices in other states, there are several methods of approval 
Mohd Shahrizan Sahid, Robiah Suratman, Hishamuddin Mohd Ali

Determination Of Special Permit Rate for Large-Scale Solar Development in Johor Based on Planner Perspective

by the state authority due to large-scale solar development, and this will be affecting the fee of the development indirectly. For example, from the land administration's perspective, some of the states use Special Permit and some of them need land conversion. This is because of the large-scale solar development that usually uses farmland, and it is contradicted with the express condition of the land as mentioned by Tenaga Nasional Berhad (2019) that solar energy generation is categorised as industrial development. Basically, Special Permit is a method for approving and allowing non-agricultural development activities carried out on agricultural land (INSTUN, 2015).

So, as to set up a new Special Permit fee especially for large-scale solar developments, the most important criterion is solar radiation as it was stressed in previous studies. This Special Permit fee should be set so that it can be used as a reference for investors and developers as it will give financial implications, including development profit and feasibility of the project (Johor Land and Minerals Office, 2020).

In order to develop large-scale solar, many elements and criteria need to be considered, where most of them come from the planner's perspective, especially in site selection. Moreover, according to Yang et al. (2017), the potential of the solar energy depends on the site or location to install the Photovoltaic (PV) instruments and it is highly related to energy that can be produced. Thus, the site selection criterion would be a crucial component that includes maximising energy production, proximity to electrical infrastructure, ecological impacts, and permitting issues (Daria \& Igor, 2017). Solar energy can be produced by absorbing sun radiation through PV solar panels to generate electricity. Hence, solar power generated is highly dependent on solar irradiance in the site (N.A. Naamandadin et al., 2018). However, the location with the best source of solar radiance is not always the best choice because there are other criteria that should be considered by planners and developers such as the economic, social, and environmental factors (Van Harren et al., 2011). The site selection criteria by previous research can be concluded as shown in Table 1. 
Table 1: Site Selection Criteria by Previous Research

\begin{tabular}{|c|c|c|c|c|c|c|c|c|c|}
\hline $\begin{array}{l}\text { Criteria/ } \\
\text { Elements/ } \\
\text { Variable }\end{array}$ & $\begin{array}{c}\text { EPA } \\
(2015) \\
\text { United } \\
\text { States }\end{array}$ & $\begin{array}{c}\text { Sabo et } \\
\text { al } \\
\text { (2016) } \\
\text { Malaysia }\end{array}$ & $\begin{array}{c}\text { Carrión } \\
\text { et al. } \\
(2008) \\
\text { Spain }\end{array}$ & $\begin{array}{l}\text { Charabi } \\
\text { and } \\
\text { Gastli } \\
\text { (2011) } \\
\text { Oman }\end{array}$ & $\begin{array}{l}\text { Uyan } \\
\text { (2013) } \\
\text { Turkey }\end{array}$ & $\begin{array}{l}\text { Sánchez- } \\
\text { Lozano et } \\
\text { al. (2013) } \\
\text { Spain }\end{array}$ & $\begin{array}{c}\text { Watson } \\
\text { and } \\
\text { Hudson } \\
\text { (2015) } \\
\text { United } \\
\text { Kingdom }\end{array}$ & $\begin{array}{c}\text { Daria } \\
\text { and Igor } \\
\text { (2017) } \\
\text { Ukraine }\end{array}$ & $\begin{array}{c}\text { Razali and } \\
\text { Zulkiflee } \\
\text { (2012) } \\
\text { Malaysia }\end{array}$ \\
\hline $\begin{array}{l}\text { Solar } \\
\text { Radiation }\end{array}$ & 1 & 1 & 1 & 1 & - & 1 & 1 & 1 & - \\
\hline $\begin{array}{l}\text { Diffuse } \\
\text { Irradiation }\end{array}$ & - & - & I & - & - & - & - & - & - \\
\hline $\begin{array}{l}\text { Equivalent } \\
\text { Sun Hours }\end{array}$ & - & - & I & - & - & - & - & - & - \\
\hline $\begin{array}{l}\text { Average } \\
\text { Temperature }\end{array}$ & - & - & I & - & - & I & - & 1 & - \\
\hline Road Access & 1 & 1 & 1 & 1 & 1 & 1 & 1 & - & - \\
\hline $\begin{array}{l}\text { Grid } \\
\text { Connection }\end{array}$ & 1 & 1 & 1 & - & 7 & 7 & 1 & 1 & 1 \\
\hline Slope & 1 & 1 & 1 & 1 & 1 & 1 & 1 & 1 & 1 \\
\hline $\begin{array}{l}\text { Aspect } \\
\text { (Orientation) }\end{array}$ & - & - & I & - & - & I & 1 & 1 & - \\
\hline $\begin{array}{l}\text { Minimum } \\
\text { Suitable Areas }\end{array}$ & 1 & - & - & - & - & 1 & - & - & - \\
\hline $\begin{array}{l}\text { Agrological } \\
\text { Capacity }\end{array}$ & - & - & - & - & - & 7 & - & - & - \\
\hline Urban Areas & 1 & - & 1 & 1 & 1 & 1 & 1 & - & - \\
\hline $\begin{array}{l}\text { Residential } \\
\text { Areas }\end{array}$ & - & - & I & 1 & I & I & 1 & 1 & 1 \\
\hline $\begin{array}{l}\text { Wildlife } \\
\text { Designations }\end{array}$ & 1 & - & I & - & 1 & I & 1 & - & - \\
\hline $\begin{array}{l}\text { Hydrographic } \\
\text { Areas }\end{array}$ & 1 & 1 & 1 & 1 & 7 & I & - & - & 1 \\
\hline Touristic Sites & - & - & - & 1 & 1 & 1 & 1 & & - \\
\hline $\begin{array}{l}\text { Landscapes } \\
\text { Designations }\end{array}$ & I & - & I & - & - & I & 1 & / & - \\
\hline Traffic Areas & - & - & 1 & 1 & 1 & - & - & - & - \\
\hline $\begin{array}{l}\text { Sand/ Dusk } \\
\text { Risk }\end{array}$ & - & - & - & 1 & - & - & - & - & - \\
\hline $\begin{array}{l}\text { Land } \\
\text { Subsidence }\end{array}$ & 1 & 1 & - & - & - & - & - & 1 & - \\
\hline Soil Erosion & 1 & - & - & - & - & - & - & - & - \\
\hline $\begin{array}{l}\text { Land } \\
\text { Ownership }\end{array}$ & - & - & - & - & - & - & - & - & 1 \\
\hline Land Use & - & 1 & - & - & - & - & - & - & 1 \\
\hline $\begin{array}{l}\text { Population } \\
\text { Density }\end{array}$ & - & - & - & - & - & - & - & - & 1 \\
\hline
\end{tabular}

Basically, solar radiation can be defined as electromagnetic radiation emitted by the sun and it can be turned into solar energy using a variety of technologies (Department of Energy United States, 2020). Furthermore, the electromagnetic radiation emitted by the sun covers a very large range of wavelength from radio waves through infrared, visible, and ultraviolet to x-rays and gamma rays. Nevertheless, the amount of solar radiation absorbed by any surface depends on how much the energy is incident on that surface including their fraction. Usually, only 40 percent of solar radiation is received by the earth's surface on clear days, and the flux of solar radiation is influenced by the angle between the direction of the sun and photovoltaic panel surface (S.C. Bhatia, 2014; R.E. Dickinson, 2003). Theoretically, the solar radiation is influenced by other suitability of site selection criteria (refer to Table 1). 
Mohd Shahrizan Sahid, Robiah Suratman, Hishamuddin Mohd Ali

Determination Of Special Permit Rate for Large-Scale Solar Development in Johor Based on Planner Perspective

Sabo et al. (2016) have analysed solar radiation which can be observed by solar panels at power selected power stations per hour and per square metre among states in Peninsular Malaysia. Based on that study, solar radiation rate is higher, that is almost or more than $5 \mathrm{kWh}$, in the northern part of Malaysia, especially in Kedah, Perlis, Penang, Perak, and Selangor (refer to Figure 2). Based on Figure 2, Johor has the lowest average SR rate of 4.1 to $4.2 \mathrm{kWh}$ compared to Kedah's $5.2 \mathrm{kWh}$. This means faster returns on investment are obtained in the northern states due to higher volume of energy sales to the National Grid.

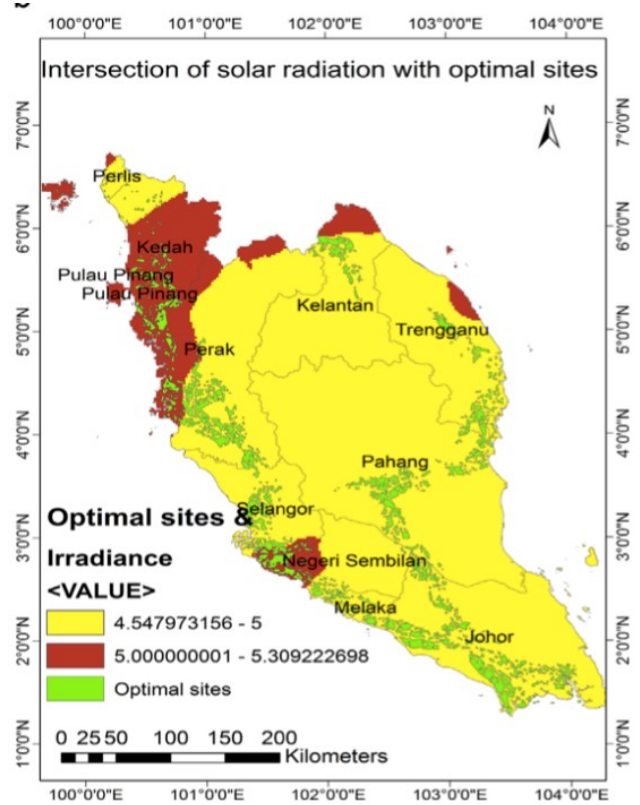

Figure 2: Intersection of Solar Radiation Value in Peninsular Malaysia. Source: Sabo et al., 2016

\section{METHODOLOGY}

This study was conducted using open interviews with selected respondents, and they were selected using purposive sampling according to the research needs and purposes. In addition, the respondents were selected due to the fact that they were directly involved in the approval of solar farms and telecommunication tower developments. Then, the data were analysed using content analysis.

Table 2: List of Respondents in the study.

\begin{tabular}{ccc}
\hline Respondent & Job Position & Agency \\
\hline R1 & Deputy Director & Johor Land and Mines \\
& (Development \& Management) & Office \\
\hline
\end{tabular}


PLANNING MALAYSIA

Journal of the Malaysia Institute of Planners (2021)

\begin{tabular}{ccc}
\hline R2 & $\begin{array}{c}\text { Chief Assistant Director, Development } \\
\text { Division }\end{array}$ & $\begin{array}{c}\text { Johor Land and Mines } \\
\text { Office }\end{array}$ \\
\hline R3 & Land Administrator & $\begin{array}{c}\text { Johor Bahru Land and } \\
\text { District Office }\end{array}$ \\
\hline R4 & Land Administrator & $\begin{array}{c}\text { Kota Tinggi Land and } \\
\text { District Office }\end{array}$ \\
\hline
\end{tabular}

\section{RESEARCH FINDING AND DISCUSSION}

Based on data in the literature above, this study has put the states of Kedah and Perak as benchmarks because they use Special Permit and have its fee especially for large-scale solar development. In 2017, Kedah was the first state to offer Special Permit method for agricultural land for the purpose of large-scale solar development without changing land conditions to the industry. Furthermore, these two states have been given the highest total energy bid approval compared to the other states by the Energy Commission, which are 355.57MW in Kedah and $248.87 \mathrm{MW}$ in Perak. So far, the total capacity of large-scale solar in these two states is the highest and it indicates that the setup of Special Permit fee in the states is accepted by the developers.

Although solar radiation in Johor is low and does not reach $5 \mathrm{kWh}$, it still has a larger potential area that can be exploited for large-scale solar development in the state. The total potential area for this development among the states of Johor, Kedah, and Perak are as shown in Table 3. Hence, the Special Permit rate can be set up based on the potential area and solar radiation value.

Table 3: Total Potential Areas, Solar Radiance Value, and Special Permit Rate

\begin{tabular}{|c|c|c|c|c|c|}
\hline \multirow[t]{2}{*}{ States } & \multicolumn{3}{|c|}{ Land Area (Acre) } & \multirow{2}{*}{$\begin{array}{c}\text { Solar } \\
\text { Radiance } \\
\text { Value } \\
(\mathrm{kWh})\end{array}$} & \multirow{2}{*}{$\begin{array}{c}\text { Special } \\
\text { Permit } \\
\text { Rate } \\
(\mathrm{RM}) / \mathrm{m}^{2}\end{array}$} \\
\hline & $\mathrm{SR}>5$ & $\mathrm{SR}<5$ & $\begin{array}{l}\text { Potential Area } \\
\text { (Acre) }\end{array}$ & & \\
\hline Kedah & $140,816.5$ & 0 & $140,816.5$ & 5.2 & 0.45 \\
\hline Perak & $256,764.9$ & $296,466.2$ & $553,231.1$ & 4.8 & 0.40 \\
\hline Johor & 0 & $601,201.6$ & $601,201.6$ & 4.1 & $\mathrm{X}$ \\
\hline
\end{tabular}

Therefore, the Special Permit rate in Johor can be set up by making a comparison of average value of X/SR in Kedah and Perak. Thus, the ratio of the value X/SR among these three states can be concluded as:

The value X/SR compared to Kedah

$\mathrm{RM} 0.32 / \mathrm{m}^{2}$

The value X/SR compared to Perak

$\mathrm{RM} 0.38 / \mathrm{m}^{2}$

The value of X/SR Johor (compared to the average value of Kedah

$\mathrm{RM} 0.35 / \mathrm{m}^{2}$ and Perak) 
Mohd Shahrizan Sahid, Robiah Suratman, Hishamuddin Mohd Ali

Determination Of Special Permit Rate for Large-Scale Solar Development in Johor Based on Planner Perspective

Thus, based on the interviews that have been held, all respondents have responded on their respective scopes. As mentioned before, this study is to determine the Special Permit rate for large-scale solar development in Johor based on solar radiance. R3 agreed on the ratio value as he said:

R3: "As we (Johor land administrators) do not have any Special Permit rate especially for large-scale solar, the ratio value of $R M 0.35 / \mathrm{m}^{2}$ is the best rate to be used as the basis of the imposition fees by making the average value of Perak and Kedah as a comparative value..."

However, R1 responded that state land administrators (Johor Land and Mines Office) have given additional discounts as solar radiance value of Johor and Kedah is much different, which is $1.1 \mathrm{kWh}$.

R1: “... additional discount of RM0.05 per square metre has been recommended by state land administrators because we are concerned that the solar radiance values between Johor and Kedah are much different. Hence, it would help the developers or landowners to get a higher profit margin through the development compared to the old rate..."

Thus, there is great potential of large-scale solar in Johor as it has a larger area compared to other states, and land administrators have also introduced some incentives as an effort to promote alternative energy in the state.

R2: “... state land administrators are committed to promoting solar energy in the state. Hence, we also gave an additional discount of RM0.05 per square metre especially for companies owned by the Johor State Government to develop large-scale solar which are implemented individually or by partnership. Furthermore, the additional discount also includes Higher Education Institutions and their subsidiaries to encourage their institution's space as a new source of income. These efforts can directly support the development of green technology in the production of clean and renewable energy in the state and nationwide."

Based on the above analysis and description, the Special Permit rate for the large-scale solar development on agricultural land can be concluded as depicted in Table 4. 
PLANNING MALAYSIA

Journal of the Malaysia Institute of Planners (2021)

Table 4: Special Permit Rate Based on Applicant

\begin{tabular}{lc}
\hline \multicolumn{1}{c}{ Applicant } & Annual Special Permit Rate \\
\hline Companies and landowners & $\mathrm{RM} 0.30 / \mathrm{m}^{2}$ \\
\hline $\begin{array}{l}\text { Company owned by the Johor State } \\
\text { Government and subsidiaries }\end{array}$ & $\mathrm{RM} 0.25 / \mathrm{m}^{2}$ \\
\hline $\begin{array}{l}\text { Higher educational institutions/state and } \\
\text { federal government institutions }\end{array}$ & $\mathrm{RM} 0.25 / \mathrm{m}^{2}$ \\
\hline
\end{tabular}

R4: “... the introduction and implementation of this new Special Permit fee rate is more reasonable, taking into account the appeal that was proposed by the developer in the application for the first solar farm in the state of Johor a few years ago. Thus, it will directly attract developers to develop solar farms as it is very profitable, while promoting this alternative energy."

Therefore, Table 5 shows the comparison of annual Special Permit rate among the states of Johor, Kedah, and Perak. Although the permit fee rate is lower compared to the other two states, it is an incentive to attract large-scale solar investment in Johor. This is because the rate of solar radiance in Johor is lower compared to these two states. In addition, Johor Land and Mines Office also recommends that only effective development areas with supporting buildings are calculated for the purpose of imposing special permits while the remaining unused areas remain as land for the use of the original purpose as stated in the title.

Table 5: Comparison of Annual Special Permit Rate Among States

\begin{tabular}{|c|c|c|c|}
\hline State & Kedah & Perak & Johor \\
\hline Annual Special & $\mathrm{RM} 0.40 / \mathrm{m}^{2}$ & $\mathrm{RM} 0.45 / \mathrm{m}^{2}$ & RM $0.25-\mathrm{RM}$ \\
\hline
\end{tabular}

\section{CONCLUSION}

In a nutshell, there are many elements and criteria for large-scale solar development approval consideration, but most of them are from the planner's perspective such as site selection. It is because site selection is the most critical part as it needs to consider many criteria. Thus, in order to set up Special Permit rates especially for large-scale solar, its drawback is analysed based on solar radiance in the state; the higher the solar radiance, the higher the solar energy and profit that can be produced. Thus, the permit fee depends on the production of solar energy as land administrators or the state government put their effort into promoting this alternative energy in the state. 
Mohd Shahrizan Sahid, Robiah Suratman, Hishamuddin Mohd Ali

Determination Of Special Permit Rate for Large-Scale Solar Development in Johor Based on Planner Perspective

\section{ACKNOWLEDGEMENTS}

This research paper would be impossible without exceptional support from various parties, including Universiti Teknologi Malaysia, supervisors, colleagues, and respondents. The enthusiasm, knowledge, and exacting attention from them have been an inspiration for us to drive our work on track until the end. Respect and appreciation are also expressed to those who have contributed to this research.

\section{REFERENCES}

Al Garni, H. Z., \& Awasthi, A. (2017). Solar PV power plant site selection using a GISAHP based approach with application in Saudi Arabia. Applied energy, 206, 12251240 .

Bhatia, S. C. (Ed.). (2014). Advanced renewable energy systems, (Part 1 and 2). CRC Press.

Bhatia, S. C. (Ed.). (2014). Advanced renewable energy systems, (Part 1 and 2). CRC Press.

Carrión, J. A., Estrella, A. E., Dols, F. A., Toro, M. Z., Rodríguez, M., \& Ridao, A. R. (2008). Environmental decision-support systems for evaluating the carrying capacity of land areas: Optimal site selection for grid-connected photovoltaic power plants. Renewable and sustainable energy reviews, 12(9), 2358-2380.

Charabi, Y., \& Gastli, A. (2011). PV site suitability analysis using GIS-based spatial fuzzy multi-criteria evaluation. Renewable Energy, 36(9), 2554-2561.

Department of Energy United States (2021). Solar Radiation Basics. Retrived from https://www.energy.gov/eere/solar/solar-radiation-basics

Dickinson, R. E. (2003). Land-atmosphere interaction. Reviews of geophysics, 33(S2), 917-922.

Energy Commision (2021). LSS Progress by Region. Retrieved from https://www.st.gov.my/en/web/industry/details/2/17

Grout, T., \& Ifft, J. (2018). Approaches to Balancing Solar Expansion and Farmland Preservation: A Comparison across Selected States. Charles H. Dyson School of Applied Economics and Management.

Hirth, L., Ueckerdt, F., \& Edenhofer, O. (2015). Integration costs revisited-An economic framework for wind and solar variability. Renewable Energy, 74, 925939.

Idris, R., \& Abd Latif, Z. (2012, July). GIS multi-criteria for power plant site selection. In 2012 IEEE Control and System Graduate Research Colloquium (pp. 203-206). IEEE.

INSTUN (2014). Laporan Kajian Prosedur Siri 2: Pengeluaran Permit Khas Penggunaan Sementara Tanah Pertanian Bagi Maksud Yang Tidak Berkaitan Pertanian : Praktis Negeri Johor.

Johor Land and Mines Office Circular No. 3/2006

Kereush, D., \& Perovych, I. (2017). Determining criteria for optimal site selection for solar power plants. Geomatics, Land management and Landscape.

Naamandadin, N. A., Ming, C. J., \& Mustafa, W. A. (2018). Relationship between Solar Irradiance and Power Generated by Photovoltaic Panel: Case Study at UniCITI 
PLANNING MALAYSIA

Journal of the Malaysia Institute of Planners (2021)

Alam Campus, Padang Besar, Malaysia. Journal of Advanced Research in Engineering Knowledge, 5(1), 16-20.

National Land Code (NLC) 1965.

North, G. R., Pyle, J. A., \& Zhang, F. (Eds.). (2014). Encyclopedia of atmospheric sciences (Vol. 1). Elsevier.

PLANMalaysia (2019). Garis Panduan Perancangan Menara dan Strtuktur Sistem Pemancar Telekomunikasi Negeri Sembilan. Jabatan Perancangan Bandar dan Desa.

Sabo, M. L., Mariun, N., Hizam, H., Radzi, M. A. M., \& Zakaria, A. (2016). Spatial energy predictions from large-scale photovoltaic power plants located in optimal sites and connected to a smart grid in Peninsular Malaysia. Renewable and Sustainable Energy Reviews, 66, 79-94.

Sánchez-Lozano, J. M., Antunes, C. H., García-Cascales, M. S., \& Dias, L. C. (2014). GIS-based photovoltaic solar farms site selection using ELECTRE-TRI: Evaluating the case for Torre Pacheco, Murcia, Southeast of Spain. Renewable Energy, 66, 478-494.

SolarLandLease (2020). Lease Rates for Solar Farms: How Valuable Is My Land? Retrieved from https://www.solarlandlease.com/lease-rates-for-solar-farms-howvaluable-is-my-land

Solarvest (2018). Solar Farms in Malaysia. Retrieved from https://solarvest.my/2018/09/21/solar-farms-malaysia/

Sustainable Energy Development Authority Malaysia (SEDA). Overview of SEDA; 2011. http://www.seda.gov.my/ [Accessed 2 April 2021].

Sustainable Energy Development Authority SEDA (n.d). Large Scale Solar. Retrieved from http://www.seda.gov.my/reportal/large-scale-solar/

United States Environmental Protection Agency. (2013). Best Practices For Siting Solar Photovoltaics On Municipal Solid Waste Landfills. Retrieved from https:/www.epa.gov/sites/production/files/201503/documents/best_practices_siti ng solar photovoltaic final.pdf

Urmee, T., \& Harries, D. (2009). A survey of solar PV program implementers in Asia and the Pacific regions. Energy for Sustainable Development, 13(1), 24-32.

Uyan, M. (2013). GIS-based solar farms site selection using analytic hierarchy process (AHP) in Karapinar region, Konya/Turkey. Renewable and Sustainable Energy Reviews, 28, 11-17.

Van Haaren, R., \& Fthenakis, V. (2011). GIS-based wind farm site selection using spatial multi-criteria analysis (SMCA): Evaluating the case for New York State. Renewable and sustainable energy reviews, 15(7), 3332-3340.

Watson, J. J., \& Hudson, M. D. (2015). Regional Scale wind farm and solar farm suitability assessment using GIS-assisted multi-criteria evaluation. Landscape and Urban Planning, 138, 20-31.

Yang, H., Ghonima, M. S., Zhong, X., Ozge, B., Kurtz, B., Wu, E., ... \& Kleissl, J. P. (2017, December). Advancing solar energy forecasting through the underlying physics. In AGU Fall Meeting Abstracts (Vol. 2017, pp. GC22B-07).

Received: $19^{\text {th }}$ August 2021. Accepted: $10^{\text {th }}$ November 2021 